\title{
Ovarian Cancer and Primary Peritoneal Carcinoma Pathologic Regional Lymph Nodes TNM Finding v7
}

National Cancer Institute

\section{Source}

National Cancer Institute. Ovarian Cancer and Primary Peritoneal Carcinoma Pathologic

Regional Lymph Nodes TNM Finding v7. NCI Thesaurus. Code C89654.

A pathologic finding about one or more characteristics of ovarian cancer or primary peritoneal carcinoma, following the rules of the TNM AJCC V7 classification system as they pertain to staging of regional lymph nodes. 